Indonesian Journal of Medicine (2018), 3(3): 168-172

https://doi.org/10.26911/theijmed.2018.03.03.07

\title{
Correlation between Hemoglobin Levels and Muscular Endurance in Soccer Athletes
}

\author{
Nur Afni Heryanti Octavia'), Muhammad Ichwan²), Putri Chairani Eyanoer²) \\ 1)Masters Program in Biomedics, Faculty of Medicine, Universitas Sumatera Utara \\ 2)Faculty of Medicine, Universitas Sumatera Utara
}

\begin{abstract}
Background: Muscular endurance is one of the important component of physical fitness in the sport of soccer player. Soccer athletes are required to contracting the muscle explosively as maximum as possible and must have high aerobic capability. This study aimed to determine the correlation between hemoglobin levels with muscular endurance in soccer athletes.

Subjects and Method: This was an analytic observational study with cross sectional design. Population was soccer player athlete who was incorporated in soccer clubs and soccer schools at Medan, North Sumatera, Indonesia. A sample of 96 soccer athletes was selected for this study. The dependent variable was muscular endurance. The independent variables were hemoglobin levels. Hemoglobin level was measured by cyanmethemoglobin method, and muscular endurance was measured by push-up test. The data was analyzed by using Spearman test.

Results: Hemoglobin levels was positively correlated with muscular endurance levels and it was statistically significant $(\mathrm{r}=0.226 ; \mathrm{p}<0.05)$.

Conclusion: This study showed hemoglobin levels correlates with muscular endurance.
\end{abstract}

Keywords: hemoglobin, muscular endurance, soccer athletes

\section{Correspondence:}

Nur Afni Heryanti Octavia. Masters Program in Biomedics, Faculty of Medicine, Universitas Sumatera Utara. Email: nurafniheryantioctavia@gmail.com.

\section{BACKGROUND}

Sports is one physical activity that can increase physical fitness. Exercise involves several systems other than the musculoskeletal system, such as the cardiovascular system, respiratory system, nervous system, excretory system, and several other systems (Mutohir and Maksum, 2007). Physical fitness can cause a decrease in speed and skills in ball games (Husaini et al., 2002). A person's physical abilities are influenced by a combination of several factors, namely internal factors and external factors. Internal factors such as genetic factors, age, and gender, while external factors are physical activity, nutritional status, health status, hemoglobin level, adequacy of rest, and smoking habits (Ahmetov and Fedotovskaya, 2015).
The ability to maintain muscular activity in a longer time is called muscular endurance (Katch et al., 2011). Muscle endurance is one component of physical fitness, in addition to strength, cardiovascular endurance, muscle flexibility, agility, speed, balance, reaction speed, body composition, and coordination (Rink et al., 2010; US Department and Human Service, 2011). Factors that determine muscle endurance are the ability of mitochondrial oxidation, ATP synthesis, muscle fiber type, and vascularization (Yan et al., 2011; Kenny et al., 2012).

Increased blood flow to skeletal muscle is needed in physical activity to provide an additional supply of oxygen and nutrients, which is not only obtained from increased cardiac output (Prior et al., 
2004). As endurance athletes who mostly use aerobic energy sources through oxidative phosphorylation, endurance athletes need higher maximal oxygen absorption (VO2max), compared to sprints and sports that use power (Lucia et al., 2005).

This study is to assess the correlation of hemoglobin levels with muscle endurance in soccer athletes.

\section{SUBJECTS AND METHOD}

This was an analytic observational study with a cross sectional design. The study population is soccer athletes who are members of the Football Club and Football School (SSB) in the city of Medan. The sampling was done by consecutive sampling technique. A sample of 96 soccer athletes aged 15-29 years old undergoing regular soccer training was selected for this study. The study subjects voluntarily signed an informed consent form and received approval from the Ethics Commission of the Faculty of Medicine, Universitas Sumatera Utara, Indonesia.

Hemoglobin levels were measured by cyanmethemoglobin. Hemoglobin levels are classified as low if $<13 \mathrm{~g} \%$ and normal if $13^{-}$ $16 \mathrm{~g} \%$ (WHO, 2001).

Push-up tests were used to determine the endurance of the study subject's muscle. Assessment of the push-up test was done by counting the total number of push-ups that can be done for one minute. The data were analyzed by Prism 7 software (GraphPad Software Inc.).

RESULTS
The subjects of the study were soccer
athletes who were members of several
football clubs between the ages of $15-21$
years and male players who did soccer
practice routinely \pm 3 times a week guided
by the coach.
In this study, the subjects were classi-
fied based on Hb levels into 2 groups,
normal Hb and less Hb (anemia). Most of
the subjects (77.1\%) had normal hemoglo-
bin levels (Table 1) and 22.9\% of them had
low Hb. Based on the amount of ability to
do push-ups per minute, the muscle
endurance of the subjects was classified
into five groups. $51 \%$ of subjects showed
very good muscle endurance and 22.9\%
showed less muscle endurance (Table 2 ).

Table 1. Distribution of hemoglobin levels

\begin{tabular}{llccc}
\hline \multicolumn{1}{c}{ Hemoglobin level } & $\mathbf{N}$ & $\mathbf{( \% )}$ & Mean Hb (g \%) & SD \\
\hline Lacking & 22 & 22.9 & 12.27 & 0.37 \\
Normal & 74 & 77.1 & 13.76 & 0.58 \\
\hline
\end{tabular}

Table 2. Distribution of muscle endurance

\begin{tabular}{lcccc}
\hline \multicolumn{1}{c}{ Muscle endurance } & $\mathbf{N}$ & $\mathbf{( \% )}$ & Mean of total push-up (x/minute) & SD \\
\hline Very poor & 1 & 1.0 & 17.00 & \\
Poor & 22 & 22.9 & 19.86 & 1.13 \\
Fair & 14 & 14.6 & 24.71 & 1.59 \\
Good & 10 & 10.4 & 32.40 & 3.41 \\
Very good & 49 & 51.0 & 44.43 & 3.85 \\
\hline
\end{tabular}

The results of this study showed that there was a positive correlation between hemoglobin levels and muscle endurance $(\mathrm{r}=0.23 ; \mathrm{p}=0.027)$. 
Indonesian Journal of Medicine (2018), 3(3): 168-172

https://doi.org/10.26911/theijmed.2018.03.03.07

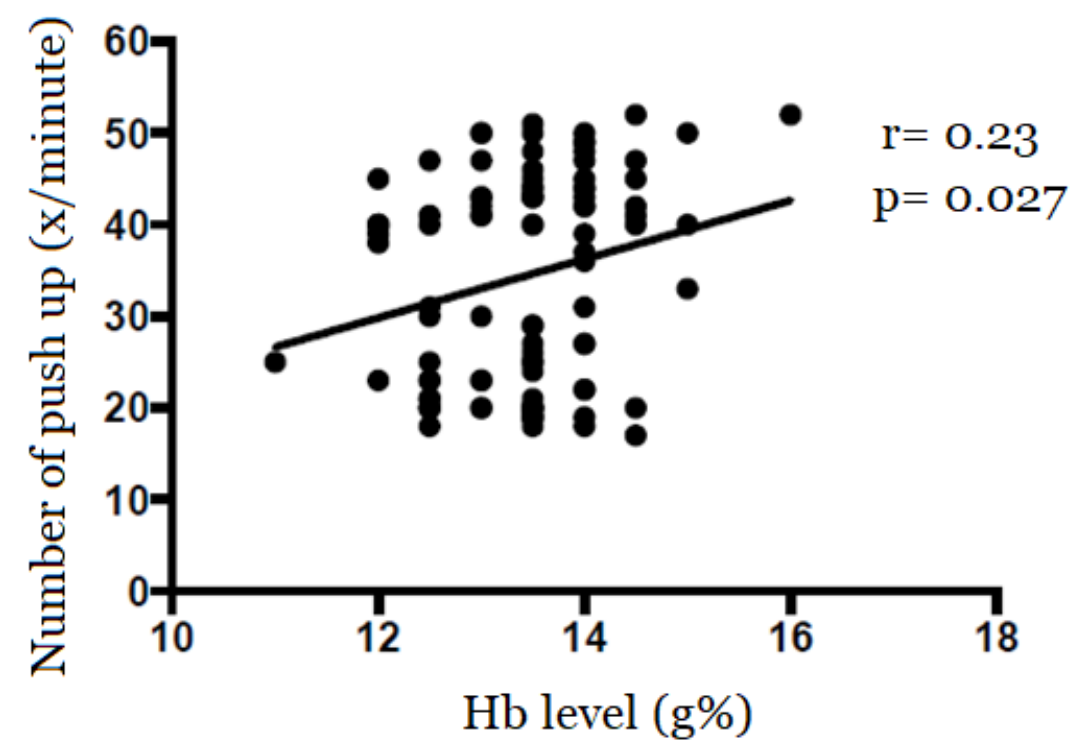

Figure 1. Correlation of hemoglobin levels with muscle endurance

$\frac{\text { DISCUSSION }}{\text { The results of this study showed that hemo- }}$ globin level was positively correlated with muscle endurance among soccer athletes $(\mathrm{r}=0.23 ; \mathrm{p}=0.027)$.

Factors that determined muscle endurance were the ability of mitochondrial oxidation, adenosine triphospate (ATP) synthesis, muscle fiber type, and vascularization (Yan et al., 2011; Kenny et al., 2012). Mitochondrial dysfunction in muscles, caused several conditions such as muscle atrophy, diabetes, and aging (SchrauwenHinderling et al., 2007; Figueiredo et al., 2008; Romanello et al., 2010).

Upregulation of mitochondrial number and function, also referred to as mitochondrial biogenesis, played an important role in exercises that cause increased muscle function and metabolic homeostasis throughout the body (Lanza et al., 2008; Lira et al., 2010). Cells can store very limited amounts of ATP and gradually produce new ATP to provide energy requirements for all cellular metabolism including muscle contraction. Cells produced ATP through one or a combination of three metabolic pathways, namely the ATP-PCr system, the glycolytic system, and the oxidative system (Kenny et al., 2012). Skeletal muscle consists of type I muscle fibers (slow-twich) and type II muscle fibers (fasttwich), which have differences in the ability to shorten speed and produce maximum strength. Slow-twitch type I muscle fibers were rich in mitochondria so that fatty acid oxidation was more dominant in mitochondria used for ATP production. While type II muscle fibers (fast-twitch) were more dominant in glucose as an energy substrate. The proportion of type I muscle fibers was positively related to insulin sensitivity and glucose transport by insulin. In parallel endurance training increased the proportion of oxidative fibers with mitochondrial biogenic responses, and was associated with increased physical exercise, fatty acid oxidation and glucose, and energy use (Gan et al., 2013). Increased blood flow to skeletal muscle was needed in physical exercise to provide an additional supply of oxygen and nutrients, which was not only obtained from increased cardiac output. The main vascular adaptation of skeletal 
muscle to endurance exercise included an increase in blood flow capacity due to increased cross-section of large blood vessels and increased muscle capillary through angiogenesis. Angiogenesis triggered by endurance training was influenced by several factors, namely, growth factors, hypoxia, and mechanical stress (Prior et al., 2004).

A study by Saunders et al., (2013) among 145 elite athletes showed that there was an increase of VO2max with hemoglobin levels. Mahastuti (2018) also obtained results that there was a significant relationship between hemoglobin levels and physical fitness carried out on basketball athletes at Universitas Negeri Semarang, Indonesia. The cardiovascular system fulfilled the needs of the substrate needed by muscles during physical activity. Physical exercise can increase total hemoglobin mass by triggering erythropoiesis and increasing the number of red blood cells 2,3-Bisphosphoglyceric acid (2,3-DPG) which can increase affinity sensitivity $\mathrm{Hb}$ O2 (Cerretelli and Di Prampero, 1985). With increasing VO2max can also increase muscle endurance (Katch et al., 2011). In this study, VO2max test was not performed. Researchers suspected that the increase in hemoglobin was accompanied by an increase in VO2max, explaining the relationship between hemoglobin and muscle endurance. Based on the results of this study concluded that hemoglobin levels has a relationship with muscle endurance in soccer athletes.

\section{REFERENCES}

Ahmetov II, Fedotovskaya ON (2015). Current progress in sports genomics. Adv clin chem.

Cerretelli P, DiPrampero PE (1985). Aerobic and anaerobic metabolism during exercise at altitude, in High Altitude Deterioration, eds Rivolier J, Cerreteli
P, Foray J, Segantini P, editors. (Basel: Karger;), 1-19.

Figueiredo PA, Mota MP, Appell HJ, Duarte JA (2008). The role of mitochondria in aging of skeletal muscle. Biogerontology 9: 67-84.

Gan Z, Kralli A, Kelly DP (2013). Nuclear receptor/microRNA circuitry links muscle fiber type to energy metabolism. J Clin Invest. 123(6):25642575 .

Husaini MA, dadang AP, Anie K, Dangsina M, Didit D (2002). Gizi atlet sepak bola Jakarta: Depkes R.I. Dirjen Kesehatan Masyarakat Direktorat Gizi Masyarakat.

Katch LV, McArdle DW, Katch, IF (2011). Essential of exercise physiology, fourth edition. Lippincott Williams \& wilkins, a wolter kluwer bussines, Philadelphia, PA 19103.

Kenney LW, Wilmore JH, Costill LD (2012). Physiology of sport and exercise, $5^{\text {th }}$ ed. Human kinetics, P.O. Box 5076, Champaign, IL 618255076. United State of America.

Lanza IR, Short DK, Short KR, Raghavaikamal S, Basu R, Joyner MJ, et al. (2008). Endurance exercise as a countermeasure for aging. Diabetes 57: 2933-2942.

Lira V, Benton CR, Yan Z, Bonen A (2010). PGC-1a regulation by exercise training and its influences on muscle function and insulin sensitivity. Am. J. physiol. Endocrinol. Metab. 299: 145.

Lucia A, Gómez-Gallego F, Barroso I, Rabadádan M, Bandrés F, Juan AFS, et al (2005). PPARGC1A genotype (Gly482Ser) predicts exceptional endurance capacity in European men. J appl physiol. 99: 344-348.

Mahastuti F, Rahfiludin Z, Suroto (2018). Hubungan tingkat kecukupan gizi, aktivitas fisik dan kadar hemoglobin 
dengan kebugaran jasmani (studi pada atlet basket di Universitas Negeri Semarang). Jurnal kesehatan masyarakat (e-journal). 6(1).

Mutohir, Maksum (2007). Sport development index. (Konsep metodologi dan aplikasi) alternatif lain mengukur kemajuan pembangunan bidang keolahragaan. PT Index.

Prior B, Yang H, Terjung R (2004). What makes vessels grow with exercise training?. J Appl Physiol. 97: 11191128.

Rink JE, Hall TJ, Williams LH (2010). Schoolwide physical activity, a comprehensive guide to desighning and conducting programs. United State of America: Human Kinetics.

Romanello V, Guadagnin E, Gomes L, Roder I, Sandri C, Petersen Y, et al. (2010). Mitochondrial fission and remodeling contributes to muscle atrophy. ЕMBO J. 29: 1774-1785.

Saunders PU, Garvican-Lewis LA, Schmidt WF, Gore JG (2013). Relationship between changes in haeemoglobin mass and maximal oxygen uptake after hypoxic exposure. Br $\mathrm{J}$ Sport Meds. 47:i26-i3o. Doi: 10.1136/bjsports-2013-092841.

Schrauwen-Hinderling VB, Kooi ME, Hesselink MK, Jeneson JA, Backes WH, vanEchteld, et al. (2007). Impaired in vivo mitochondrial function but similar and intramyocellular lipid content in patient with type 2 diabetes mellitus and BMI-matched control subjects. Diabetologia 50: 113-120.

US Department of Human Service (2011). Physical activity for everyone: glossary of terms.

WHO (2001). Iron deficiency anemia assessment, prevention and control. A guide for programe manager. https://www.who.int/nutrition/publications/micronutrients/anaemia_iron_ deficiency/WHO_NHD_01.3/en/

Yan Z, Okutsu M, Akhtar YN, Lira V (2011).Regulation of exercise-induced fiber type transformation, mitochondrial biogenesis, and angiogenesis in skeletal muscle. Journal of applied physiology. 110:264-274. 